\title{
80 歳以上の超高齢者の腹部大動脈瘤に対する外科治療の検討
}

\author{
日比野成俊土屋幸治中島雅人 \\ 佐々木 英樹松本春信 内藤祐 次
}

\begin{abstract}
80 歳以上の超高齢者の腹部大動脈瘤に対する外科治療の特徴, 合併症, 手術成績, 手術適応などについて検 討した. 1981 年から 2000 年に当院で施行された腹部大動脈瘤に対する人工血管置換術を行った 223 例を対 象とした。これらを手術施行時の年齢によって, 80 歳以上の群（O 群）23 例と 80 歳未満の群（Y 群）200 例に分け, 術前, 術後の合併症, 手術成績などについて検討した。病院死亡率は待機手術症例のみでは両群 とも $0 \%$ であり, 緊急手術症例のみでは 0 群 $57.1 \%$ に対して $\mathrm{Y}$ 群 $6.1 \%$ と有意に 0 群のほうが高かった。 緊急手術症例は $Y$ 群 $(16.5 \%)$ に比べて 0 群 $(30.4 \%)$ のほうが有意に多かった。術前合併症では, 腎機 能低下, 慢性閉塞性肺疾患, 消化器系合併症は 0 群のほうが多かった。冠動脈病变, およびそれ以外の心血 管系合併症は両群間で有意差はなかった。術後合併症では腸閉塞, 肺炎, 心血管系の合併症は 0 群で有意に 多く, 死亡例はいずれもこれらの合併症によるものであった. 80 歳以上の超高齢者の腹部動脈瘤に対する人 工血管置換術は, 待機手術については, ほかの年齢層と同様に安全に施行しうると考えられるが, 緊急手術 の成績は不良であり，早期発見，早期治療が成績向上のためには重要であると考えられた．日心外会誌 31 巻 5 号 : 321-324 (2002)
\end{abstract}

Keywords：超高齢者, 腹部大動脈瘤, 人工血管置換術

\begin{abstract}
Surgical Treatment of Abdominal Aortic Aneurysm in Octogenarians
Narutoshi Hibino, Koji Tsuchiya, Masato Nakajima, Hideki Sasaki, Harunobu Matsumoto and Yuji Naito (Department of Cardiovascular Surgery, Yamanashi Prefecture Central Hospital, Kofu, Japan)

We reviewed 223 cases of surgical treatment for abdominal aortic aneurysm in octogenarians in this hospital between 1981 and 2000, and investigated the characteristic features, complications, and indications of the operation. The cases were divided into two age groups. Group O included 23 cases of octogenarians, and Group Y included 200 cases of patients under 80 years old. The average age was 68.6 years old in group Y (33-79 years old), and 83 years old in group O (8093 years old). The hospital mortality rate was $0 \%$ in elective operation cases. In emergency operation case, Group O had a hospital mortality rate of $57.1 \%$, significantly higher than the $6.1 \%$ for group $\mathrm{Y}$. The hospital mortality rate was $17 \%$ in group $\mathrm{O}$ and $0.5 \%$ in group $\mathrm{Y}$. The rate of emergency operation case was significantly higher in group O (30.4\%) compared to group $\mathrm{Y}(16.5 \%)$. As for the preoperative complications, group $\mathrm{O}$ had more cases of renal dysfunction, COPD and gastrointestinal complication. As for the coronary artery disease and other cardiovascular complications, there were no significant differences between the groups. In the postoperative complication, group $\mathrm{O}$ had more cases of ileus, pneumonia, and cardiovascular disease. These complications were fatal in group $O$. These results suggest that surgical treatment for abdominal aortic aneurysm was performed safely in both groups for elective operations. Because the results of emergency operations are poor, early diagnosis and treatment seem to be important for the improvement of operative results. Jpn. J. Cardiovasc. Surg. 31 : 321-324 (2002)
\end{abstract}

高齢化社会の到来とともに，血管外科の手術対象となる 患者の年齢も年々高齢化している．また，ライフスタイル の欧米化に伴い動脈瘤をはじめとする血管疾患の数も年々 上昇傾向にある。

とくに近年の腹部大動脈瘤に対する外科的手術の成䋶は

2001 年 8 月 10 日受付, 2002 年 1 月 23 日採用

山梨県立中央病院心臓血管外科 $\overline{\mathbf{T}} 400-0027$ 甲府市富士見 11-1
非常に良好であり，手術の対象年齢も徐々に拡大されてき ている ${ }^{1)}$ ししかし，80歳以上の超高歯者に対する報告はま だ少なく, 手術適応などについて議論が多い.

今回われわれは当院での過去 20 年間の経験から， 80 歳 以上の超高齢者の腹部大動脈瘤に対する手術に関する特 徴, 合併症, 手術成績, 手術適応などについて検討した。 


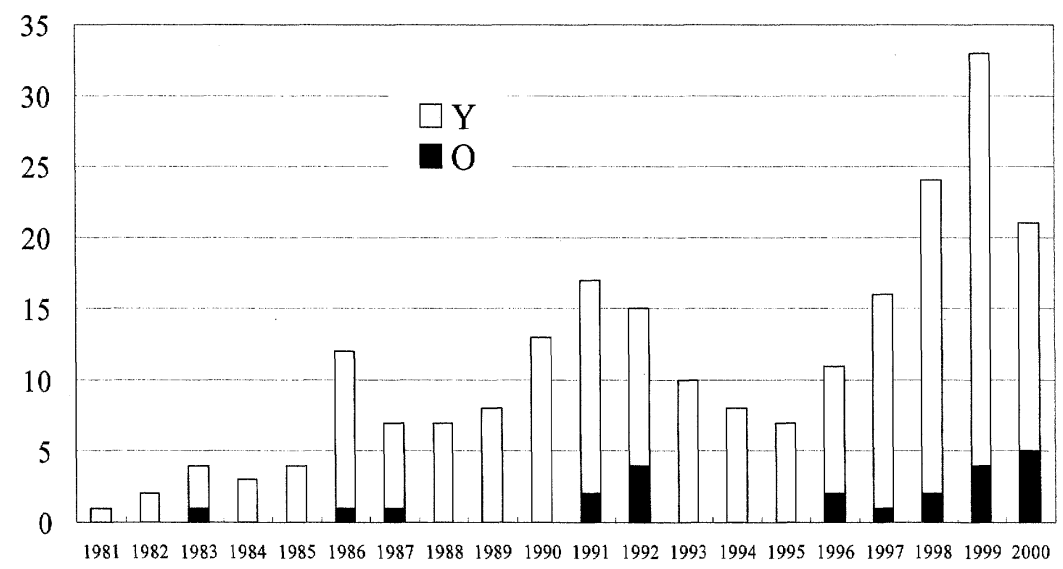

図 1 腹部大動脈に対する手術症例数

腹部大動脈瘤の症例数は全体的に年々増加している傾向がみられ，とくに 80 歳以上の症例は 1990 年代後半には毎年 10〜30\%の割合でみられるようになっ てきた.

\section{対 象}

1981 年から 2000 年までの過去 20 年間に当院において, 腹部大動脈瘤に対する人工血管置換術を行った 223 例を対 象とした. 食生活の欧米化に伴う動脈硬化疾患の増加や予 防医学の進歩による早期発見例の増加によって腹部大動脈 瘤の症例数は全体的に年々増加する傾向がみられ，とくに 80 歳以上の症例は 1990 年代後半には毎年 10～30\%の割合 でみられるようになってきた（図1）。

これらを手術施行時の年齢によって, 80 歳以上の群 (O 群） 23 例と 80 歳未満の群（Y 群） 200 例に分け, 術前, 術後の合併症，手術成績などについて検討した。平均年齢 は $\mathrm{O}$ 群 83 歳（80９3 歳），Y 群 68.6 歳（33〜 79 歳）で あった.腹部大動脈瘤の最大径法術中計測值で $\mathrm{O}$ 群 $63.9 \pm 12.3 \mathrm{~mm}$, Y 群 $60.8 \pm 14.4 \mathrm{~mm}$ であり, 両群間に 有意差を認めなかった（表 1)。また動脈瘤の範囲は腎動 脈上型が 2 例, 傍腎動脈型が 2 例で, そのほかは全例腎動 脈下型であった。

手術適応については，手術に対する同意が患者，家族か ら得られたうえで, 待機手術では腹部大動脈瘤の最大径が $50 \mathrm{~mm}$ 以上の症例とした. 緊急手術症例では動脈瘤の切 迫破裂, または破裂症例で, 入院時ショック状態であって も強心剂，昇圧剤などの投与により血行動態が維持される 症例は手術適応とした。しかし発症から時間が経過してお り，自尿がなく，検査上明らかな多臓器不全を認める症例 は手術適応外とした。

全症例とも術前に腹部造影 CT によって腹部大動脈瘤の 評価を行った。待機手術症例では，心臓カテーテル検査を 行い, 腹部大動脈と心機能, 冠動脈病変の評価を行ったう えで, 必要に応じて心合併症に対する治療を先行して行っ
表 1 Case

\begin{tabular}{lccc}
\hline Group & $\mathrm{O}$ & $\mathrm{Y}$ & Total \\
\hline Number & 23 & 200 & 223 \\
Age & $80-93$ & $33-79$ & \\
Mean age & 83 & 68.6 &
\end{tabular}

Max diameter of aneurysm ( $\mathrm{mm})$

Emergency

operation

$63.9 \pm 12.3 \quad 60.8 \pm 14.4$

40

$(30.4 \%)$

33

$(17.9 \%)$

た。

手術は全例腹部正中切開で開腹し, 腹腔内より後腹膜腔 へ到達し, 動脈瘤を切除し, 人工血管置換術を行った。下 腸間膜動脈は，原則として開存している場合は再建を行っ た.

\section{結 果}

病院死亡率（入院中の死亡率）は待機手術症例のみでは 両群とも $0 \%$ であり, 緊急手術症例（入院後 24 時間以内 に手術を行った症例）のみでは O 群 $57.1 \%$ に対して Y 群 $6.1 \%$ と有意に $\mathrm{O}$ 群のほうが高く, 結果的に全手術症例で の病院死亡率は $\mathrm{O}$ 群 $17 \%, \mathrm{Y}$ 群 $1 \%$ であった（表 2). 死 亡例の原因は, Y 群では大量出血に伴う循環不全 1 例, 腎不全による多臓器不全 1 例, $\mathrm{O}$ 群では肺炎 2 例, 術後急 性心筋梗塞 1 例, 腸管虚血による多臓器不全 1 例であり, 全例とも緊急手術症例であった。

緊急手術症例は $\mathrm{Y}$ 群 $(16.5 \%)$ に比べて $\mathrm{O}$ 群 （30.4\%）のほうが有意に多かった（表 1). 緊急手術は全 例とも動脈瘤の破裂，または切迫破裂によるものであっ た。破裂の形式は雨群ともに, 後腹膜腔に破裂する 
表 2 Hospital mortality（\%)

\begin{tabular}{lcl}
\hline Group & $\mathrm{O}$ & $\mathrm{Y}$ \\
\hline Emergency operation & 57.1 & 6.1 \\
Elective operation & 0 & 0 \\
Total & 17 & 1 \\
\hline
\end{tabular}

緊急手術症例のみでは $\mathrm{O}$ 群 $57.1 \%$ に対し てY群 $6.1 \%$ と有意に O 群のほうが高 加た。

表 3 Type of ruptured aneurysm

\begin{tabular}{lcr}
\hline Type & O (\%) & \multicolumn{1}{c}{ Y $(\%)$} \\
\hline Closed & $3(42.8)$ & $21(63.6)$ \\
Sealed & $2(28.6)$ & $7(21.2)$ \\
Opened & $2(28.6)$ & $4(12.1)$ \\
IVC & 0 & $1(3.1)$ \\
\hline
\end{tabular}

Closed type: 後腹膜腔に破裂,

Sealed type: 周囲組織の反応によっ て破裂口が完全に閉鎖, Opened type：腹腔内に破裂.

表 4 Preoperative complications

\begin{tabular}{llcc}
\hline Group & $\mathrm{O}(\%)$ & $\mathrm{Y}(\%)$ & \multicolumn{1}{c}{$p$} \\
\hline Renal failure* & $5(21.7)$ & $3(1.3)$ & 0.005 \\
COPD* $^{*}$ & $2(8.7)$ & $2(0.9)$ & 0.009 \\
Gastrointestinal disease* & $6(26.1)$ & $7(3.0)$ & $<0.001$ \\
Coronary artery disease & $6(26.1)$ & $17(39)$ & 0.46 \\
$\quad$ Post CABG & $1(4.35)$ & $10(4.3)$ & 0.89 \\
$\quad$ Combined with CABG & $0(0.0)$ & $2(0.9)$ & 0.63 \\
Other cardiovascular & $3(13)$ & $22(9.4)$ & 0.77 \\
disease & & & \\
Total & $14(60.9)$ & $80(34)$ & \\
\hline
\end{tabular}

術前合併症では，腎機能低下，慢性閉塞性肺疾患，消化器系合 併症は $\mathrm{O}$ 群のほうが多く, 冠動脈病変, およびそれ以外の心 血管系合併症は両群間で有意差はなかった。 ${ }^{*} p<0.05$.

closed type が一番多く, 続いて周囲組織の反応によって 破裂口が完全に閉鎖されている sealed type，腹腔内に破 裂する opened typeの順に多かったＹ（群に比べて $\mathrm{O}$ 群 のほうが opened type の占める割合が多かった。 Y 群に 1 例下大静脈に破裂していた症例を認めた（表 3 ).

術前合併症では，腎機能低下（CCr $<40 \mathrm{ml} / \mathrm{min})$, 慢 性閉塞性肺疾患 (肺気腫, 気管支喘息), 消化器系合併症 （消化管潰瘍, 腸閉塞, 胆石, 鼠径へルニア）は $\mathrm{O}$ 群のほ うが多かった。なお，ここで腎機能低下以外の他蔵器合併 症とは，それぞれの診断に基づいて他科で定期的に診察， 治療を受けている症例とした。冠動脈病変の合併は $\mathrm{O}$ 群 で $26 \%$, Y 群で 17\%にみられ, 冠動脈バイパス術の既往 のあるものは両群ともに $4 \%$ 程度であり, 有意差を認めな なかった、腹部大動脈瘤, 冠動脈病変以外の心血管系の合 併症（高血圧，不整脈，閉塞性動脈硬化症，心筋症，弁膜 症, 胸部大動脈瘤）も，両群間で有意差を認めなかった
表 5 Postoperative complications

\begin{tabular}{lcccc}
\hline Group & $\mathrm{O}(\%)$ & $\mathrm{Y}(\%)$ & $p$ \\
\hline Renal failure & $0(0)$ & $2(0.9)$ & 0.63 \\
Pneumonia* & $5(21.7)$ & $0(0)$ & $<0.001$ \\
Ileus* & $5(21.7)$ & $3(1.3)$ & $<0.001$ \\
Other gastrointestinal & $1(4.35)$ & $3(1.3)$ & 0.33 \\
disease & & & \\
Cardiovascular event* & $3(13)$ & $2(0.9)$ & $<0.002$ \\
Total & $10(43.5)$ & $10(4.3)$ & \\
\hline
\end{tabular}

術後合併症では腸閉塞，肺炎，心血管系の合併症は $\mathrm{O}$ 群で有 意に多く，死亡例はいずれもこれらの合併症によるものであっ た. $* p<0.05$.

（表 4）.

術後合併症では腎機能低下 $(\mathrm{CCr}<40 \mathrm{ml} / \mathrm{min})$ ，腸閉 塞以外の消化器系合併症（消化管出血，潰瘍）は両群間に 有意差を認めなかった，腸閉塞，肺炎，心血管系の合併症 (術後発症の心筋梗塞, 心不全, 不整脈, 急性動脈閉塞症 高血圧，不整脈，閉塞性動脈硬化症，心筋症，弁膜症，胸 部大動脈瘤）は $\mathrm{O}$ 群で有意に多く，O群での死亡例はい ずれもこれらの合併症によるものであった（表 5).

\section{考察}

近年, 生活様式の変化, 高齢化社会の到来, 予防医学の 発展などによって，腹部大動脈溜に対する外科手術は，件 数が年々増加するとともに，対象となる患者の平均年齢も 高くなってきている.とくに80 歳以上の超高齢者に対す る手術症例も近年増加傾向にあり，当院でも 1990 年代の 後半から全体の 10～30\%の割合で毎年みられるように なっている。

80 歳以上の超高齢者に対する腹部大動脈瘤の手術成績 は, 待機的手術では 80 歳以下の群とほぼ変わらず, 病院 死亡率は 5\%以下といわれているが，緊急手術症例では手 術死亡が 9〜20\%, 病院死亡が $43 \sim 65 \%$ となってい $3^{2 \sim 7)}$. 死亡率の低い報告の多くは，手術開始時に血圧， 尿の流出が保たれている全身状態の良好な症例を対象とし て, 手術死亡のみについて検討しているため, 術前より状 態が悪く, 術後合併症のために死亡した症例を含んでおら ず，外科的治療の成績を正確に反映していない可能性があ る.したがって 80 歳以上の超高歯者では周術期の合併症 も考慮に入れた病院死亡率では，とくに緊急手術では，80 歳未満の群に比べて有意に死亡率が高いと考えられる。わ れわれの結果でも待機手術症例では年齢による手術成績の 有意な差は認めなかったが, 緊急手術症例では, 超高齢者 のほうが, 病院死亡率が有意に高かった。

一方, 周術期の合併症について, Alonso-Perez らは75 歳以上の腹部大動脈瘤破裂症例 112 例の検討で, 予防不良 
因子として術前には腎機能障害 $(\mathrm{Cr}>1.4 \mathrm{mg} / \mathrm{dl})$, 術後 には腎機能障害, 心合併症をあげており, 死因としては, 敗血症，DIC，腸管虚血が多いと報告している8．また， Party らは超高齢者の手術では無症状の潜在性のものを含 めた，心，肺，腎合併症に対する対策が重要であると述べ ている，そのために，術前には心合併症予防のために術前 にタリウムシンチを施行して虚血病変を検索し, 必要であ れば心臓カテーテル検查を施行し，詳細な評価を行ったう えで，治療を行う。また肺合併症の予防のために早期抜 管, 離床をすすめ, 腎合併症の予防のために周術期の輸液 管理に十分注意する必要があるとしている ${ }^{6)}$.今回のわれ われの結果では, 80 歳以上の超高歯者群では, 術前は, 腎機能低下, 慢性閉塞性肺疾患, 術後は, 腸閉塞, 肺炎, 心血管系の合併症が有意に多く, 緊急手術の病院死亡例は いずれもこれらの合併症によるものであった，当院でも合 併症の予防として, 待機的手術では原則的に術前に心臓力 テーテル検査を行い冠動脈病変, 心機能について精査して いる. その結果約 $20 \%$ の症例に心血管系の合併症を認め, CABG を先行して行ったものが 11 例, 同時手術が 2 例 あった。:また, 消化器, 呼吸器合併症の予防のため, 可能 な限り早期の離床に努めている. その結果, 待機手術症例 ではこうした合併症による死亡を認めていないが, 緊急手 術症例では，これらの合併症に対する精査が十分できず， とくに超高齢者では術前状態が不良なため, 術後も早期離 床が困難にならざるを得ず, 病院死亡率が高くなっている と考えられる。

腹部大動脈瘤の破裂率は 5 年で, $50 \mathrm{~mm}$ 以下では 26〜 41\%，70 mm 以上では $95 \%$ 以われている9. 80 歳 以上の平均余命が $6 \sim 8$ 年であり, 術後の 5 年生存率は待 機手術症例では $67 \sim 85.7 \%$, 緊急手術では $34 \%$ といわれ ている ${ }^{10)}$ また, Brown らは $50 \mathrm{~mm}$ 以下の腹部大動脈瘤 を前向きに 6 カ月ごとにフォローした 492 例の試験で 50〜 $56 \mathrm{~mm}$ で破裂した 6 例を認め，45〜 49 mm では瘤の 大きさが毎年 $7 \mathrm{~mm}$ 増加すると報告し, $4.5 \mathrm{~cm}$ を待機手 術の境界としている ${ }^{11}$. 今回のわれわれの結果でも, 待機 的手術では 80 歳未満の症例と手術成績に有意な年齢差を 認めないことから， $50 \mathrm{~mm}$ 以上の腹部大動脈瘤は可能な 限り早期に待機的に手術を行うのが望ましいと考えられ る. 一方, 緊急手術症例では周術期の重篤な合併症により 成績が不良になっているので Falk らも述べているように 重篤な心, 脳, 腎, 合併症をもつ症例は手術適応からはず れると思われる4)。むしろいかにして早期発見, 早期治療 に努め, 緊急手術症例数を減らすかが重要であると考えら れる.
また, 近年, 発展しつつあるステントグラフトは, 通常 の開腹手術に比べて低侵襲であり, 合併症の多い超高齢者 に対しても有用な手段の一つである.しかし, 適応につい てはいくつかの制限があり, また術後 30 日以内の病院死 亡率は 5.6 10\% ${ }^{11)}$, 術中合併症は 17 26\% ${ }^{12)}$ といわれ ており，遠隔期成績はまだ不明な点も多いため，施行にあ たっては十分な検討を要すると思われる.

\section{結語}

80 歳以上の超高齢者の腹部動脈瘤に対する人工血管置 換術は, 待機手術については, ほかの年齢層と同様に安全 に施行しうると考えられるが, 緊急手術の成績は不良であ り, 早期発見, 早期治療が成績向上のためには重要である と考えられた。

\section{文献}

1) Rutledge, R., Oller, D. W., Meyer, A. A. et al. : A statewide, population based, time-series analysis of the outcome of ruptured abdominal aortic aneurysm. Ann. Surg. 223 : 492-505, 1996.

2) Party, P. S., Lloyd, W. E., Chang, B. B. et al.: Aortic replacement for abdominal aortic aneurysm in elderly patients. Am. J. Surg. 166 : 191-193, 1993.

3) Ihara, A., Chiba, Y., Kimura, T. et al. : Abdominal aortic aneurysmectomy in the octogenarian. Ann. Thorac. Cardiovasc. Surg. 4: 247-250, 1998.

4) Falk, V., Vettelschoss, M., Walther, B. et al.: Surgical treatment of abdominal aortic aneurysms of octogenarians. Cardiovasc. Surg. 4: 727-731, 1996.

5) Kazmars, A., Perkins, A. J., Jacobs, L. A. et al. : Outcomes after abdominal aortic aneurysm repair in those $>80$ years of age: recent veterans affairs experience. Ann. Vasc. Surg. 12: 106-112, 1998.

6) Party, P. S., Lloyd, W. E., Chang, B. B. et al. : Aortic replacement for abdominal aortic aneurysm in elderly patients. Am. J. Surg. 166 : 191-193, 1993.

7) Chalmers, R. T. A., Stonebridge, P. A., John, T. G. et al. : Abdominal aortic aneurysm in the elderly. Br. J. Surg. $80: 1122-1123,1993$.

8) Alonso-Perez, M., Segura, R. J., Pita, S. et al. : Surgical treatment of ruptured abdominal aortic aneurysm in the elderly. Ann. Vasc. Surg. 13 : 592-598, 1999.

9) Haimovici, H.: Vascular Surgery, 4th ed., Blackwell Science, Massachusetts, 1996, pp. 800-801.

10) Sugawara, Y., Takagi, A., Sato, O. et al. : Surgical treatment of abdominal aortic aneurysm in octogenarians. Jpn. Circ. J. 60 : 328-333, 1996.

11) Brown, P. M., Pattenden, R. and Gutelius, J. R.: The selective management of small abdominal aortic aneurysms: The Kingston study. J. Vasc. Surg. 15 : 21, 1996.

12) May, J., White, M. J., Yu, W. et al. : Concurrent comparison of endoluminal versus open repair in the treatment of abdominal aortic aneurysm: analysis of 303 patients by life table method. J. Vasc. Surg. $27: 213-220,1998$. 